\title{
THE EFFECT OF EDUCATION USING MODIFICATION MODULE TOWARDS NUTRITIONAL INTAKE DURING PREGNANCY IN KENDARI, INDONESIA
}

\author{
Kartini $^{1,2 *}$, Muh Syafar ${ }^{3}$, A. Arsunan Arsin ${ }^{4}$, Burhanuddin Bahar $^{5}$, Farming $^{2}$, \\ Fitriyanti $^{2}$
}

\author{
${ }^{1}$ Doctoral Studies Program Faculty of Medicine, Hasanuddin University, Indonesia \\ ${ }^{2}$ Department of Midwifery, Health Polytechnic Kendari, Indonesia \\ ${ }^{3}$ Health Education and Promotion, Faculty of Public Health, Hasanuddin University, Makassar Indonesia \\ ${ }^{4}$ Epidomiology Department, Faculty of Public Health, Hasanuddin University, Makassar Indonesia \\ ${ }^{5}$ Nutritional Study Program, Faculty of Public Health, Hasanuddin University, Makassar Indonesia
}

Accepted: 24 May 2016

*Correspondence:

Kartini

Email : thynny2430@yahoo.com

Copyright: $\odot$ the author(s), YCAB publisher and Public Health of Indonesia. This is an open-access article distributed under the terms of the Creative Commons Attribution Non-Commercial License, which permits unrestricted non-commercial use, distribution, and reproduction in any medium, provided the original work is properly cited.

\section{ABSTRACT}

Background: Energy metabolism speeds up during pregnancy that requires pregnant women to have extra amount of nutritions. Provision of education on nutrition during pregnancy is an effort to prevent and tackle malnutrition.

Aim: This study aimed to determine the effect of education using modification module towards nutritional intake during pregnancy in Kendari, Indonesia

Methods: This was Quasi Experimental study with pre-post design. There were 4 groups in this study, which were: 1) The group that received educational intervention using a modification module from the MHC book of the Department of Health, 2) The group that received educational intervention using MHC book of the Department of Health, 3) The group that only used modification modules from MHC book of the Department of Health, and 4) The group that only used the MHC book of Department of Health. The intervention was given for 6 months. Seventy eight of 4-months pregnant women were selected in this study. Data were collected by using 24 hours food recall instrument, and questionnaire adopted from Child and Maternal Nutrition Survey's Questionnaire of Faculty of Public Health, Hasanuddin University. Data were analyzed by using Wilcoxon test and Kruskal Wallis test.

Results: Results showed there was an effect of education by using the module modifications to the intake of nutritions during pregnancy. Increased nutrient intake was higher in pregnant women using a module class modifications.

Conclusion: Education affects nutritional intake of pregnant women. Changes in nutritional intake was higher in group 1 (education modules with modifications), compared with the education group $\mathrm{MCH}$ handbook. It is suggested that mothers should improve the nutrition during pregnancy for the better growth of the fetus, composition and metabolic changes in the mother's body.

Key Words : education, nutrient intake, pregnancy care 


\section{INTRODUCTION}

Pregnancy and childbirth is a natural event, which is sometimes accompanied by the risk of pregnancy and delivery in the form of complications for both mother and baby, such as hemorrhage, eclampsia and infection. ${ }^{1}$ These complications however are the biggest causes of maternal and infant mortality, which can be seen from Demographic and Health Survey Results Indonesia (IDHS) in 2012, showed an increase in maternal mortality rate (MMR) from the previous year 2007. The maternal mortality rate (MMR) in Indonesia in 2007 was 228 per 100,000 live births, increased to 359 per 100,000 live births. IDHS 2012 also explained that the IMR was decreased, but it still remains high from the results of the IDHS 2007 that was about 32 and 34 deaths per 1,000 live births. ${ }^{2}$

One of factors influencing the complications is nutrition in pregnancy. Pregnant women with severe malnutrition fetus are at risk of Intrauterine Growth Restriction (IUGR) and Low Birth Weight Babies (LBW), metabolic disorders such as insulin resistance, diabetes, hypertension and dyslipidemia, and atherosclerosis. $^{3,4,5,6,7}$ All these risks however due to inadequate nutrients and oxygen needed for growth and development of organs and tissues, so that the early detection of pregnancy to reflect the growth of the fetus is necessary. On the other hand, pregnant women who are lack of protein and micronutrients (vitamin A, thiamine, iron and zinc, and magnesium) are at risk for the occurrence of IUGR and LBW, while pregnant women having excessing nutrients are at risk for the occurrence makrosomia in fetus. ${ }^{8,9,10,11,12}$

In line with that, the negative impact of the nutritional problems in the short term is the disruption of brain development, intelligence, impaired physical growth and impaired metabolism in the body. While the consequence for the long-term is decreasing cognitive abilities and learning achievement, low immunity, and high risk for the emergence of diabetes, obesity, heart and blood vessels, cancer, stroke, and disability.

One way to prevent stunted growth and death of the fetus is prenatal care, which can be performed by knowlegeable pregnant women. All the information about pregnancy actually can be obtained from a variety of media. However, the knowledge and information from health care providers are more accurate, and give a good impact on the behavior of pregnant women. ${ }^{13}$ The educational approach by health workers is the best approach than the current coercive approach to improve the knowledge of mothers about care during preganancy. Changes in behavior as a impact of the education through a learning process is expected to be life long learning. ${ }^{14}$ Therefore, education in pregnant women is a lesson to create a relationship between midwives and pregnant women to maintain the pregnancy. ${ }^{15}$

The educational approach that can be performed is through the class for pregnant women. Having a class is one of the most important activities in antenatal care in the community, as an effort of learning for mothers, husbands and familes through the method of joint learning activities in the classroom, which is facilitated by health officials to prepare pregnant women having safe delivery and comfortable. ${ }^{16,17}$ Literatures stated that the class for pregnant women should be consisted of a pregnant woman and her partner to maintain and preserve the baby. ${ }^{18}$ It was also indicated that pregnant women who attended the classes were better than pregnant women who did not attend the classes. ${ }^{19}$ It also increased the knowledge of them, and increase the antenatal visitations. ${ }^{20,21}$ In addition, the class also brought the benefit for pregnant women to reduce pain during childbirth, anxiety, stress and depression. ${ }^{22,23,24}$ Therefore, this study aimed to determine 
the effect of maternal education on nutritional intake of pregnant women in Kendari, Indonesia

\section{METHODS}

This was Quasi Experimental study with pre-post design. There were 4 groups in this study, which were: 1) The group that received educational intervention using a modification module from the MHC book of the Department of Health, 2) The group that received educational intervention using MHC book of the Department of Health, 3) The group that only used modification modules from MHC book of the Department of Health, and 4) The group that only used the MHC book of Department of Health. This research was conducted in Kendari July 2015 to January 2016. The samples in this study were mostly pregnant women with 4 months gestational age in Kendari Indonesia. The samples were 80 pregnant women divided into four groups with each group a sample consisted of 20 pregnant women by purposive sampling. But the sample was reduced to 78 pregnant women because 2 of them were excluded due to having 8 months gestational age.

Data were collected by asking the respondents to fulfill the questionnaires, which was adopted from Child and Mental Nutrition Survey's Questionnaire from Faculty of Public Health, Hasanuddin University. The measurement of nutritional intake of respondents was using 24-hours food recall instrument that was conducted 3 times: the beginning phase, three weeks after beginning phase, and 2 months after the second measurement.

The intervention of Educational approach was conducted 12 times for 6 months in every two weeks during pregnancy, starting from 4 months gestational age until delivery. Data were analyzed using Wilcoxon test and Kruskal Wallis test.

\section{RESULTS}

Characteristics of Respondents

Table 1. Characteristics of Respondents

\begin{tabular}{|c|c|c|c|c|c|c|c|c|c|}
\hline \multirow{3}{*}{ Characteristics } & \multicolumn{8}{|c|}{ Group } & \multirow{3}{*}{ p-value } \\
\hline & \multicolumn{2}{|c|}{1} & \multicolumn{2}{|c|}{2} & \multicolumn{2}{|c|}{3} & \multicolumn{2}{|c|}{4} & \\
\hline & $\mathrm{n}(\mathbf{2 0})$ & $\%$ & $\mathrm{n}(20)$ & $\%$ & $n(20)$ & $\%$ & n(18) & $\%$ & \\
\hline \multicolumn{10}{|l|}{ Age } \\
\hline$<20$ & 2 & 10,0 & 0 & 0 & 0 & 0 & 3 & 16,7 & \\
\hline $20-35$ & 18 & 90,0 & 20 & 100,0 & 20 & 100,0 & 15 & 83,3 & 0,097 \\
\hline \multicolumn{10}{|l|}{ Education } \\
\hline SMA & 19 & 95,0 & 17 & 85,0 & 19 & 95,0 & 17 & 94,4 & \\
\hline Diploma & 0 & 0 & 1 & 5,0 & 1 & 5,0 & 0 & 0 & 0,675 \\
\hline $\mathrm{S} 1$ & 1 & 5,0 & 2 & 10,0 & 0 & 0 & 1 & 5,6 & \\
\hline \multicolumn{10}{|l|}{ Work } \\
\hline Working & 1 & 5,0 & 3 & 15,0 & 3 & 15,0 & 3 & 16,7 & 0,602 \\
\hline Not Working & 19 & 95,0 & 17 & 85,0 & 17 & 85,0 & 15 & 83,3 & \\
\hline \multicolumn{10}{|l|}{ Income } \\
\hline$<$ Rp. 1.650 .000 & 7 & 35,0 & 8 & 40,0 & 8 & 40,0 & 5 & 27,8 & 0,846 \\
\hline$\geq$ Rp. 1.650 .000 & 13 & 65,0 & 12 & 60,0 & 12 & 60,0 & 13 & 72,2 & \\
\hline \multicolumn{10}{|l|}{ Parity } \\
\hline Primi/nullipara & 14 & 70,0 & 14 & 70,0 & 11 & 55,0 & 14 & 77,8 & 0,492 \\
\hline Multipara & 6 & 30,0 & 6 & 30,0 & 9 & 45,0 & 4 & 22,2 & \\
\hline
\end{tabular}


Table 1 showed that The characteristics of the respondent were classified into: age, education, occupation, income, and parity. The age of respondents ranged from 18 to 35 years, and the group of respondents were mostly between 20-35 years old, considered as safety age for pregnant and birth delivery. The education of respondents was mostly SMA (senior high school), few were S1 (bachelor level). The working status showed that the majority respondents were not working, while the income level were mostly $<$ Rp. 1.650.000, and Parity status was that the respondents were primipara (the first time for pregnant), while multipara means more than 1 times given birth. Chi-square test results showed there was no difference between maternal age, parity, education, employment and family income and parity with $p$-value $>0.05$. It was indicated that the characteristics of respondents were homogeneous.

\section{Nutritional Intake}

Nutritional intake is a sufficient level of nutrients derived from food consumed by the mothers. The measurement of maternal nutritional intake used recaal 24 hours. Low intake if the nutritional intake $<90 \%$ of RDA of pregnant women, and normal is $90-110 \%$ RDA of nutrient intake of pregnant women.

Table 2. Changes in Levels of Nutrient Intake Respondents before and after Intervention

\begin{tabular}{|c|c|c|c|c|c|c|c|c|c|}
\hline \multirow{3}{*}{ Nutrient Intake } & \multicolumn{8}{|c|}{ Group } & \multirow{3}{*}{$\mathbf{p}$} \\
\hline & \multicolumn{2}{|c|}{1} & \multicolumn{2}{|c|}{2} & \multicolumn{2}{|c|}{3} & \multicolumn{2}{|c|}{4} & \\
\hline & $\mathrm{n}(20)$ & $\%$ & $\mathrm{n}(20)$ & $\%$ & $\mathrm{n}(20)$ & $\%$ & $\mathrm{n}(18)$ & $\%$ & \\
\hline \multicolumn{10}{|l|}{ Pre test (T0) } \\
\hline Less & 5 & 25,0 & 5 & 25,0 & 4 & 20,0 & 2 & 11,1 & \\
\hline Normal & 14 & 70,0 & 13 & 65,0 & 16 & 80,0 & 16 & 88,9 & 0,479 \\
\hline More & 1 & 5,0 & 2 & 10,0 & 0 & 0,0 & 0 & 0,0 & \\
\hline \multicolumn{10}{|l|}{ Post test 1 (T1) } \\
\hline Less & 0 & 0,0 & 2 & 10,0 & 0 & 0,0 & 1 & 5,6 & \\
\hline Normal & 20 & 100,0 & 14 & 70,0 & 20 & 100,0 & 13 & 72,2 & 0,029 \\
\hline More & 0 & 0,0 & 4 & 20,0 & 0 & 0,0 & 4 & 22,2 & \\
\hline \multicolumn{10}{|l|}{ Post test 2 (T2) } \\
\hline Less & 0 & 0,0 & 2 & 10,0 & 0 & 0,0 & 1 & 5,6 & \\
\hline Normal & 18 & 90,0 & 10 & 50,0 & 19 & 95,0 & 13 & 72,2 & 0,025 \\
\hline More & 2 & 10,0 & 8 & 40,0 & 1 & 5,0 & 4 & 22,2 & \\
\hline
\end{tabular}

Table 2 showed that the nutritional intake of the respondents experienced a change of less became normal. Group 1 had the highest increase from 7 to 20 people at $\mathrm{T} 1$ measurements. The test results with chi square statistic indicated the difference between the nutrient intake of the four groups on the measurement of $\mathrm{T} 1$ and $\mathrm{T} 2$ measurements with $\mathrm{p}<0.05$, while there was no difference between the four groups with $\mathrm{p}>0.05$ in $\mathrm{T} 0$.
The percentage of maternal nutrient intake at the beginning, the end of $\mathrm{T} 1$, and averaged of percentage changes in nutrient intake after receiving education through modification module. The percentage of the value was obtained from maternal nutritional intake compared with $\mathrm{AKG}$, and multiplied by $100 \%$. Changes score nutrient intake during pre-test, post test 1 and post test 2 can be seen in Table 3 . 
Table 3. Changes in Nutritional Intake Score of Respondents before and after Intervention

\begin{tabular}{|c|c|c|c|}
\hline Nutritional Intake & T0 & T1(p) & T2 \\
\hline Group I $(\mathrm{n}=20)$ & $94,65 \pm 6,59$ & $100,90 \pm 5,35(0,001)$ & $108,20 \pm 3,94(0,000)$ \\
\hline Group 2 $(\mathrm{n}=20)$ & $97,70 \pm 9,32$ & $103,50 \pm 8,64(0,001)$ & $107,1 \pm 10,63(0,001)$ \\
\hline Group 3 $(\mathrm{n}=20)$ & $97,35 \pm 5,22$ & $101,60 \pm 1,96(0,001)$ & $104,25 \pm 3,51(0,000)$ \\
\hline Group 4 $(\mathrm{n}=18)$ & $96,39 \pm 7,21$ & $99,06 \pm 8,05(0,007)$ & $100,28 \pm 9,47(0,003)$ \\
\hline
\end{tabular}

Table 3 showed all respondents had improved nutritional intake compared to the baseline measurements. Wilcoxon test results showed there was no statistical difference in nutritional intake at the beginning of the measurement with the second measurement, and the third measurement. Changes in nutritional intake responses to significant post test 1 in all groups.

Figure 1. Changes in nutrient intake mother

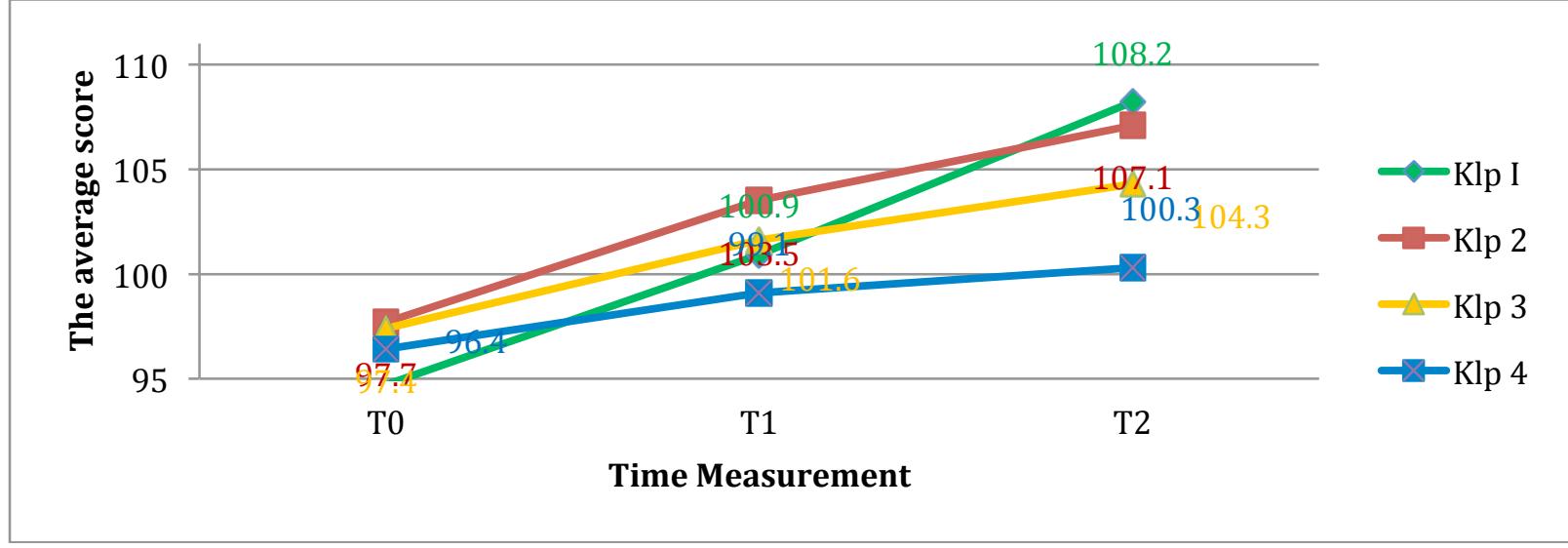

Figure 1 showed that at the beginning of the measurement, the average percentage of respondents nutritional intake was between 94.7 to $97.7 \%$, while at the end of the study, the average percentage of maternal nutritional intake was between 100.3 to 108.2. There was improved attitudes of highest score in group 1, then group 2; group 3 and group 2. The difference of lowest nutrient intake $(\Delta 1)$ score was obtained when T1 nutritional intake was reduced by an initial nutrient intake score; and nutrient intake $\Delta 2$ score was obtained when $\mathrm{T} 2$ (end) reduced the early nutritional intake score. The difference of nutrient intake score $\Delta 1$ was between $2.7 \%-6.3 \%$, while nutrient intake score $\Delta 2$ was between $3.9 \% \quad-12.6 \%$. Kruskal Test was used to compare the different scores of nutrient intakes between the groups. The comparison of different nutritional intake between the groups can be seen in Table 4.

Table 4. Difference score of nutritional intake respondents before and after intervention

\begin{tabular}{|c|c|c|c|c|}
\hline Knowledge & $\Delta 1$ & $\mathrm{p}$ & $\Delta 2$ & $\mathrm{p}$ \\
\hline Kelompok I $(\mathrm{n}=20)$ & $6,3 \mathrm{a}$ & & $13,6 \mathrm{a}$ & \\
\hline Kelompok 2 $(\mathrm{n}=20)$ & $5.8 \mathrm{a}$ & 0,182 & $9.4 \mathrm{~b}$ & 0,001 \\
\hline Kelompok 3 $(\mathrm{n}=20)$ & $4.3 \mathrm{a}$ & & $6.9 \mathrm{c}$ & \\
\hline Kelompok 4 $(\mathrm{n}=18)$ & $2.7 \mathrm{~b}$ & & $3.9 \mathrm{c}$ & \\
\hline
\end{tabular}


Table 4 indicated that the results of Kruskal indicated that there was no difference in nutritional intakes between the four groups at the second and third measurement. The group 1 remained the highest increased score. In $\Delta 1$ and $\Delta 2$ there were also different scores of nutrition between group 1 and group 2 with group 3 and 4 . In $\Delta 2$, there was a different score of nutrient intake of different groups 1 and 2 with groups 3 and 4 . It showed that there was a class effect of maternal education through the improvement of nutrition respondents score.

\section{DISCUSSIONS}

The results showed an increase of the average percentage of respondents after getting nutrition information in a class of pregnant women. The improved nutrition of respondents significantly started on the second measurement (post-test I). While changes of nutrient intake of respondents were significant in the post test 2. This indicateed that there was an influence of nutritional education to change the respondents. Based on the Kruskal Wallis test, it was found the differences in nutrient intake changes in post 1 and post 2 between the four groups. Thus, it can be concluded that there was the effect of education by using a modified module in improving nutritional intake of pregnant women compared to the baseline measurements.

Provision of education on nutrition in pregnancy is an effort to prevent and tackle malnutrition. Knowledge about nutrition is an important promotional tool in the pregnancy, because it affects the behavior of pregnant women to consume fruits, vegetables, folic acid and can control weight gain during pregnancy and improve the health of mothers and bayi. ${ }^{24,25}$ Education about nutrition is more influential when giving nutritional support, such as foods or micronutrient supplements, ${ }^{26}$ therefore midwife's role is crucial in supporting the health of pregnant women and baby. ${ }^{27}$ Knowledge of nutrition has also a positive effect on the awareness of nutrition in pregnancy. Pregnant women who received education on nutrition increased $31 \%$ after a given knowledge. The ideal foods of pregnant women should contain enough calories (energy) and all the essential nutrients (components of food that can not be synthesized by the body itself, but is necessary for health and growth) and must be in the appropriate number of grocery harinya. ${ }^{28}$

On the other hand, pregnancy increases energy metabolism while also increasing the need of nutrients during pregnancy for growth and development of the fetus, composition and metabolic changes in the mother's body. A pregnant woman requires foods containing nutrients and adapted to different body condition and fetal development. Additional food for pregnant women can be provided by increasing both the quality and quantity of food daily pregnant women, and also provide additional special formula to pregnant women. If the diet during pregnancy is not fulfilled, it can lead to malnutrition, and susceptible to interference. Malnutrition in pregnant women can cause risks and complications in pregnant women, such as anemia, slowly gaining weight, and infection. At the time of delivery, malnutrition can lead to long time birth, labor prematurely (premature), bleeding after childbirth, and delivery operations.

However, the need for nutrients will be met if the mother consumes a variety of foods. It is because the more diverse of the food, the better quality of that food. But, the need for energy and nutrients is dependent on the factors of age, gender, body weight, physical activity and others. ${ }^{29}$ There have been various attempts have been made to prevent and 
address the problem of malnutrition such as giving iron tablets in anemia women, and feeding nutrients for pregnant women. The ideal foods of pregnant women should contain enough calories (energy) and all the essential nutrients (components of food that can not be synthesized by the body itself, but is necessary for health and growth. ${ }^{28}$ Lack of nutrition at the time of conception or young pregnant can cause fetal death or disability. Similarly, pregnant women with a height $<145 \mathrm{~cm}$, and weighing $<45 \mathrm{~kg}$ are at risk for the fetus. ${ }^{30}$ The difference occurs in the first trimester of fetal life until the shortage of certain substances, which are needed in the differentiation process that can lead to the formation of an organ perfectly, or cannot survive the fetus. The rapid growth occurrs mainly in the last trimester of pregnancy the mother, then the food shortages in this period can inhibit growth until the baby is born with a weight and length less than it should be. Malnutrition is a major cause of death and disease in children and women, increasing premature births, and risks of heart disease and diabetes. Malnutrition moves from malnourished mothers to malnourished babies. If the baby is a girl, then she potentially becomes malnourished mothers, and the cycle will continue. Malnutrition among rural women of reproductive age are still very high. As people who live in poverty are more vulnerable to infection, disease and malnutrition, therefore information on nutrition in rural areas is required to view and modify the program's impact on maternal health interventions hamil. ${ }^{30}$

\section{CONCLUSION}

Education affects nutritional intake of pregnant women. Changes in nutritional intake was higher in group 1 (education modules with modifications), compared with the education group $\mathrm{MCH}$ handbook. It is suggested that mothers should improve the nutrition during pregnancy for the better growth of the fetus, composition and metabolic changes in the mother's body

\section{REFERENCES}

1. Badan Pusat Statistik, Kantor Menteri Negara Kependudukan/Badan Koordinasi Keluarga Berencana Nasional, Departemen Kesehatan, \& Macro International Inc, Survei Demografi dan Kesehatan Indonesia 2012. Jakarta, 2013.

2. Saimin, J. Manoe, Murah, Hubungan Antara Berat Badan Lahir Dengan Status Gizi Ibu Berdasarkan Ukuran Lingkar Lengan Atas. Makassar: Bagian Obstetri Dan Ginekologi Fakultas Kedokteran Universitas Hasanuddin, 2006.

3. Wegierek, D.S, Intrauterine nutrition: long-term consequences for vascular health.

INTERNATIONAL JOURNAL OF WOMEN'S HEALTH, 2014. 6: 647-656.

4. Wegierek, D.S. (2011) Szamotulska K., Fetal development and risk of cardiovascular diseases and diabetes type 2 in adult life. MED WIEKU ROZWOJ, 2011. 15(3):203-215.

5. Kramer, M.S., The epidemiology of adverse pregnancy outcomes: an overview. J NUTR,2013. 133:1592S$1596 \mathrm{~S}$.

6. Zhang, Z., Kris-Etherton, P.M., Hartman, T.J., Birth weight and risk factors for cardiovascular disease and type 2 diabetes in US Children and adolescents: 10 year results from NHANES. MATERN CHILD HEALTH J. Epub, 2013.

7. Levin, B.E., Metabolic imprinting: critical impact of the perinatal environment on the regulation of energy homeostasis. PHIL TRANS R SOC B, 2006. 361(1471):1107-1121. 
8. Bolesta, M., Szostak-Wegierek, D., Zywienie kobiety podczas ciazy., Czesc II. Witaminy $i$ skladniki mineralne [Nutrition during pregnancy. Part II. Vitamins and minerals]. ZYW CZLOW METAB, 2009. 36(4):656-664. Polish.

9. Beard, J., Iron requirements and adverse outcomes. In: Lammi-Keefe CJ, Couch SC, Philipson EH, editors. Handbook Of Nutrition In Pregnancy. TOTOWA, NJ: HUMANA PRESS, 2008; 233-254.

10. Williamson, C.S., Nutrition in pregnancy. NUTRITION BULLETIN, 2006. 31(1):28-59.

11. Drake, A.J. Reynolds RM., Impact of maternal obesity on offspring obesity and cardiometabolic disease risk. REPRODUCTION, 2010. 140(3):387-398.

12. Widodo, S., Abu, A., Psikologi Belajar. Jakarta: PT Rineka Cipta, 2012.

13. Notoatmodjo,S., Ilmu Perilaku Kesehatan. Jakarta: PT Rineka Cipta, 2010.

14. Morisky., Donald E, Ang., Alfonso, Krousel-Wood, J. Ward., Harry., Predictive Validity of a Medication Adherence Measure in an Outpatient Setting.THE JOURNAL OF CLINICAL HYPERTENSION (ISSN 1524-6175), 2008. 10 No.5.

15. Kemenkes RI., Kelas Ibu Hamil. Jakarta: Kemenkes RI, 2012.

16. Svensson, J., Barclay, L., Cooke, M., Effective Antenatal Education: Strategies Recomemended By Expectant an New Parent. THE JOURNAL OF PERINATAL EDUCATION, 2008. 17:4.

17. Ahlden, I., Ahlehagen, S., Dahlgren, L.O., Josefsson, A., Parents' Expectations About Participating in Antenatal Parenghood Education Classes. THE JOURNAL OF
PERINATAL

EDUCATION, 2012.21:11-17.

18. Ummah, F., Peningkatan Perawatan Kehamilan Melalui Kelas Ibu Hamil di Puskesmas Lamongan. SURYA, 2013.02(XV).

19. Pangesti, W.D., Kusuma, I.R., Pengaruh Kelas ibu Hamil Terhadap Perilaku Ibu Dalam Asuhan Antenatal di Puskesmas Patikraja Banyumas. JURNAL ILMIAH ILMU-ILMU KESEHATAN, 2013.

20. Al-Ateeq, M., Al-Rusaiess, A., AlDughaither, A., Perceptions and effects of antenatal education. SAUDI MED J, 2013. 34(12):1287.

21. Escott, D., Slade P., Spiby, H., Preparation for pain management during childbirth: The psychological aspects of coping strategy development in antenatal education. ELSEVIER CLINICAL PSYCHOLOGY REVIEW, 2009. 29:617-622.

22. Benediktsson, I., McDonald, S.W., Vekved,M., McNeil, D.A., Dola, S.M., Tough, S.C., Comparing Centering Pregnancy to Standard Prenatal Care Plus Prenatal Education. BMC PREGNANCY AND CHILDBIRTH, 2013. 13:55.

23. Bahrami, N., Simbar, M., Bahrami, S., The Effect of Prenatal Education on Mother's Quality of Life During First Year Postpartum Among Iranian Women: A Randomized Controlled Trial. INTERNATIONAL JOURNAL OF FERTILITY AND STERILITY, 2013. 7;3:169-174.

24. Thangaratinam, S., Rogozinska, E., Jolly, K., Glinkowski, S., Roseboom, T., Tomlison, J.W., Kunz, R., Mol, B.W., Coomarasamy, A., Khan, K.S., Effect of Interventions in Pregnancy on Maternal Weight and Obstetric Outcomes: meta-analysis of 
Randomised Evidence. BMJ, 2012. 344:e2088.

25. Girard, A.W., Oludea, O., Nutrition Education and Counselling Provided during Pregnancy: Effects on Maternal, Neonatal and Child Health Outcomes. PAEDIATRIC AND PERINATAL EPIDEMIOLOGY, 2012. 26 (1): 191-204.

26. Arrish, J., Yeatman, H., Williamson, M., Midwives And Nutrition Education During Pregnancy: A Literature Review. WOMEN AND BIRTH, 2014. 27(1):2-8.

27. Fallah, F., Pourabbas, A., Delpisheh, A., Veisani, Y., Shadnoush, M., Effects of Nutrition Education on Levels of Nutritional Awareness of Pregnant Women in Western Iran. INTERNATIONAL JOURNAL OF ENDOCRINOLOGY AND METABOLISM, 2013. 13:175-178.
28. Hossain, B., Sarwar, T., Reja, S., Akter, N., Nutritional Status of Pregnant Women in Selected Rural and Urban Area of Bangladesh. J NUTR FOOD SCI, 2013.

29. Almatsier, S., Prinsip Dasar Ilmu Gizi.. Jakarta: PT.Gramedia Pustaka Utama, 2003.

30. Kruger, H.S., Pharm, M., Maternal Anthropometry and Pregnancy Outcomes: a Proposal For the Monitoring of Pregnancy Weight Gain in Outpatient Clinics in South Africa. CURATIONIS, 2005. 28(4):40-49

Cite this article as: Kartini, Syafar $M$, Arsin AA, Bahar B, Farming, Fitriyanti. The Effect of Education Using Modification Module towards Nutritional Intake during Pregnancy in Kendari, Indonesia. Public Health of Indonesia 2016; 2(2):84-92 